\title{
DETECTION OF SOME INSECTICIDE RESIDUES IN MILK AND INFLUENCE OF HEAT TREATMENTS AND BACTERIAL FERMENTATION AGAINST THESE INSECTICIDES
}

\author{
${ }^{1}$ Amany M. Shalaby, ${ }^{2}$ Marcel F. Galab and ${ }^{3}$ Nashwa M. Abdel Atti \\ ${ }^{1,2}$ Port-Said Lab of Food Hygiene, ${ }^{3}$ Ismailia Lab Department of food Hygiene, \\ Animal Health Research Institute, Dokki,Giza, Egypt
}

\begin{abstract}
Sixty buffalo's raw milk samples were analyzed for detection of insecticides residues in Port Said governorate. The analysis revealed that presence of organochlorine compounds (DDT, DDE, DDD, Lindan and Dieldrin in 46.67\%, 48.33\%, 38.33\%, 45\% and 30\% of samples respectively . while organophosphorous compounds could be detected in 21.66\%, 11.66\%and 8.33\% for Diazinon, Malathione and Dursban respectively. None of the milk samples exceeded the permissible limit. Heat treatment and Bacterial fermentation for some positive samples revealed reduction in residual percent (DDT, DDE, Diazinon, Malathion and Dursban). In contrast, residues of DDD were showed slightly increased by heat treatment, while Lindan and Dieldrin were relatively constant by heat treatment and Bacterial fermentation. The public health importance of insecticide residues in milk and the recommendation for eliminating the milk contamination and safeguard the consumers against the serious effect of these pollutants were discussed.
\end{abstract}




\section{INTRODUCTION}

Milk is an essential food of high nutritive value specially for infants and the aged persons. Milk considered as a cheap source of nearly complete food since its good source not only for protein but also fats, major minerals needs and essential nutrients that the body needs as calcium,protein,potassium and some other vitamin ;A, B2, B12,Niacin and phosphorous, (Kholif et al.,1994 and Abou-Arab 1996).

Milk is considered as a source of excretion of some toxic compounds (organochlorine compounds) which are excreted by simple diffusion Both basic substances and lipid-soluble compounds can be excreted into milk, where basic substances can be concentrated in milk since milk is more acidic $(\mathrm{Ph}=6.3-6.5)$ than blood plasma $(\mathrm{PH}=7.3-7.5)$ (Ebbing and Wrighton 1987).

The contamination of milk is considered as one of the main dangerous aspects in the last few years .Milk can be contaminated by residues of organochlorine and organophosphorous through a variety of sources (Abou-Arab1996 and Fontcuberta et al., 2008.) Insecticides reach milk through exposure of dairy animals to direct spraying with insecticides used for controlling of external parasites on animals or via polluted food and soil (Snelson and Tuinstra 1979 and Waliszewski et al.,1997).

Organochlorine pesticides (OC) were widely used world wide until restrictions were introduced in the late seventies both in Europe and the USA, initially for DDT (Fontcuberta et al., 2008). Some of these pesticides are still wildly used by farmers because of their effectiveness 
and their broad-spectrum activity (Amoah et al., 2006) and also are being extensively used in tropical countries in malaria control programs and against livestock ectoparasites and agricultural pests (Curus 1994). Persistent OC compounds such as DDT andHCB play an important role in chronic poisoning and take part in a number of pathological processes (Lembowiez et al., 1991 Sitarska et al., 1991).

Fat solubility of these compounds is responsible for their varied concentrations in the tissues and their accumulation in the lipoproteins of the cell membranes, thus changing their structures and permeability (Chowdhury et al. 1990 and Antunes et al. 1993). Organochlorine pesticides are able to significantly decrease the ability of highly purified human natural killer ( $\mathrm{N} \mathrm{K}$ ) cells to lyse tumor cells after exposure, ranging from 1 hour to 6 days (Beach and Whalen2006). Pesticide exposure independently or in synergism with modifiable risk factors, is recognized as an important environmental risk factor associated with hemopoetic cancers, cancers of the prostate, pancrease, liver and other body systems (Jaga and Dharmani, 2005).

However the use of most OC pesticides in Egypt was restricted. Nevertheless, they are present in the environment. The fermented dairy products such as yoghurt are also important. Since their beneficial effects make them a valuable component in the diet of infants and elderly .Dairy products can be contaminated by pesticides by improper handling and by feeding the 3/1/2017animals on contaminated feeds. Many researches have demonstrated that organochlorine concentrations become considerably reduced in the course of food processing. The removal of residues is influenced by the type of food, location of pesticide and especially by the type of processing operation (Abou -Arab 1997).

Kafrelsheikh Vet. Med. J. Vol. 9 No. 1 (2011) 
This study was performed to detect the presence of some organochlorine and organophosphrous insecticides in buffalo's milk samples and to evaluate the influence of heat treatments (pasteurization, boiling, sterilization and bacterial fermentation) on the level insecticides residues in milk.

\section{MATERIAL AND METHODS}

\section{Materials:}

Milk: A total of 60 buffaloes' raw milk samples (1 litre of each) randomly collected from different areas in Port-Said Governorate and its surrounding areas over a period of summer months of insecticides application in agriculture and veterinary purposes. Each sample was received in a glass bottle and immediately cooled in an ice box and then quickly stored at $-20^{\circ} \mathrm{C}$ until analysis. Before analysis, the milk samples were shaken handly and subjected directly to extraction process.

\section{Methods of Analysis:}

Insecticide residues were extracted from different samples and analyzed according the method described by (Toyoda et al., 1990, Pesticide Analytical Manual 1991 and A.O.A.C 1995) using Hewlett Packard Model 5890 G.L.C.equiped with electron Ni63 and flame photometric Detector.

\section{Heat treatments:}

Raw positive samples of buffaloes milk ( $5 \%$ fat) were exposed to each of the following treatments:

1- Pasteurization: 7 positive milk samples were heated to $73^{\circ} \mathrm{C}$ for $15 \mathrm{sec}$ and cooled to $10^{\circ} \mathrm{C}$ (Laboratory Pasteurization). 
2- Sterilization: 7positive milk samples were sterilized in an autoclave, at $121^{\circ} \mathrm{C}$ for $5 \mathrm{~min}$.

3- Boiling: 7positive milk samples were heated with stirring to boiling point for five minutes then cooled.

4- Yoghurt Processing: 7 positive milk samples were heated to $80-82$ ${ }^{\circ} \mathrm{C}$ in a water bath for 20 minutes, and cooled to $40-42{ }^{\circ} \mathrm{C}$. Milk were inoculated with $2 \%$ yoghurt starter culture (1:1) mixture of Streptococcus thermophilus and Lactobacillus bulgaricus at $40^{\circ} \mathrm{C}$ for3-4 hours until it was coagulated and then refrigerated overnights as described by Egyptian Organization for Standardization (E.O.S. 1970).

After heat treatment and bacterial fermentation of (7) positive samples. Each sample was analyzed for insecticide residues. Achieved data were statistically analyzed.

\section{RESULTS AND DISCUSSION}

\section{1- Insecticide residues in milk:}

The analysis of 60 samples of raw milk as shown in Table (1) revealed that the organochlorine insecticides residues were detected at percentage of $46.67 \%, 48.33 \%, 38.33,45 \%$ and $30 \%$ for p.p.DDT, p.p.DDE, p.p.DDD, Lindan and Dieldrin respectively. The concentration of p.p.DDT were ranged from 0.045 to $0.196 \mu \mathrm{g} / \mathrm{L}$ with a mean value of $0.090 \pm 0.020$ The p.p.DDE varied from 0.080 to $0.197 \mu \mathrm{g} / \mathrm{Lwith}$ an average value of $0.135 \pm 0.009$. Also, the concentration of p.p.DDD were ranged from 0.033 to $0.206 \mu \mathrm{g} / \mathrm{L}$ with a mean value of $0.099 \pm 0.015$ .Moreover the average value of Lindan was $0.039 \pm 0.010$ and its quantities lie between 0.011 to $0.059 \mu \mathrm{g} / \mathrm{L}$ but the mean value of Dieldrin

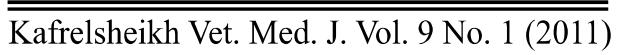


was $0.092 \pm 0.027$ and its residues varied from 0.060 to $0.165 \mu \mathrm{g} / \mathrm{L}$ .Aldrin couldn't be detected in raw milk samples.These results are nearly similar to those reported by Ali et al., (1993), Samia (1997)and Nevin and Eman(2009). However, none of the detected organochlorine residues exceed the permissible limit. In this respect the average levels are below the acceptable maximum residues level (MRL) mentioned by F.A.O and WHO (1972). These limits are 1.25 P.P.m. for total DDT and its isomers (DDD, DDE) , 0.020 P.P.m .for Lindan and 0.15 P.P.m. for Dieldrin and Aldrin . In contrast Kannan et al., (1992) and Amr et al., (1996) recorded that some of organochlorine compounds in milk were found to be above the MRL of FAO and WHO. On the other hand DDT was the highest residue concentration in raw milk. Battu et al. (2004) revealed that DDT residues were exceeding the MRL in $74 \%$ of samples of liquid milk in India. In this aspect, Waliszewski et al. (2004) demonstrated that DDT is an insecticide that has been widely used because of its chemical stability. DDT is Known to be degrade into DDD, DDE and certain other metabolites in the environment and such compounds are lipid soluble and bioaccumulate. They added that DDE is the major metabolite and may account for about $25 \%$ or more of the total DDT. Further more, the frequent detection of this organochlorine in raw milk fat showed that their persistance in the environment is due to their use in agriculture, volatilization from contaminated soils and thus contaminated growing plants.

The present results recorded that Aldrin residues was not detected in all examined milk samples which may be due to continuous degradation into Dieldrin within living tissues through different metabolic processes (Dogheim et al., 1989 and Samia1997). 
Regarding to the analytical result of organophosphorous compounds as shown in Table (1) Diazinon residues could be detected in $21.66 \%$ of examined milk samples ranging from 5.33 to $184.00 \mu \mathrm{g} / \mathrm{L}$ with a mean value of $130.120 \pm 24.6$ such level is considered slightly high and might be due to large scale of application of Diazinon for the control of external parasites during this period of the year. These results are nearly similar with those reported by Pagliuca et al., (2006). In contrast Toyoda et al., (1990) and Kholif et al., (1994) recorded higher concentration of Diazinon residues in milk samples. On contrary AbouDonia et al., (2010) recorded that none of the buffalo's milk samples revealed the presence of an organophosphorous residue. However the food and Agriculture organization and world Health organization (1972), recorded that the acceptable daily intake for Diazinon residues in milk was been set at a maximum of $2 \mu \mathrm{g} / \mathrm{Kg}$ body weight. Analytic results revealed that Malathione residues in milk samples were 11.66 and its residues were varied from 0.048 to $0.357 \mathrm{ug} / \mathrm{L}$ with a mean value of $0.107 \pm 0.036$. These values are considered lower than those reported by Abd-Alla et al., (1991) and Samia (1997). Results revealed the presence of Dursban in $8.33 \%$ of milk samples with a mean concentration value of $0.056 \pm 0.016 \mathrm{ug} / \mathrm{L}$. such results are in agreement with those reported by El-Ghannam et al.,(1987)who detected Dursban residues in milk after spraying stayed for beyond the toxic level for human. WHO(1973) reported that the level of $0.03 \mathrm{mg} / \mathrm{Kg}$ body weight per day appear to be the minimal response level in human to Dursban, while the tolerance of $0.014 \mathrm{mg} / \mathrm{Kg}$ body weight per day orally for one month is a level causing no harmful effect. Table (1) demonstrated that raw milk samples were free from detectable amounts of Lannte, Dimethoate, Parathion and Phosalone. On the other hand Stijve (1984), Camoni et al., (1990), AbdAlla et al., (1991) and Pagliuca et al., (2006) reported deposition of these residues and other pollutants in milk. 
The present study revealed that organochlorine residues in milk samples are comparatively higher in comparison with organophosphorous residues. In this aspect Downey (1971) explained that organophosphorous insecticides are rapidly decomposed by physicochemical processes in the environment as well as by enzymatic processes in the animal body which prevents the building up of significant residues in milk. In addition I.D.F. (1979) reported that most of these compounds are water soluble, animals secrete most of them in urine and faeces so little or no residues would be secreted in milk.

Moreover,organochlorine are very stable compounds resulted in extensive environmental pollution, have high fat and water accumulated in adipose tissue of milking animals, then high residues would be secreted in milk. The most dangerous problem of milk pollution with insecticides, is that it causes changes in milk content which give chance to be teratogenic substances to human consumption and cause a generation of unexpected diseases .Since some insecticides accumulate in foetal tissues indicating placental transfer of such chemicals, in addition to renal failure, liver cirrhosis and optic never manifestation, (Dixon 1980 and Amr 1992).

However, it can be generally stated that the contamination of milk by OCPS and PCBS (polychlorinated biphenyls) has declined in developed countries as a result of the restrictive measures in pesticide usage applied by governments following the recommendation of the World Health Organization (WHO) and the Food and Agriculture Organization (FAO). 
Amany M. Shalaby et., al.

Table (1): Insecticides residues of organochlorine and organophosphorous in buffalo's raw milk samples ( $\mu \mathrm{g} /$ litre).

\begin{tabular}{|c|c|c|c|c|c|c|c|c|}
\hline \multirow{2}{*}{$\begin{array}{c}\text { Type of } \\
\text { Insecticides }\end{array}$} & \multirow{2}{*}{$\begin{array}{c}\text { No. of } \\
\text { Samples }\end{array}$} & \multirow{2}{*}{$\begin{array}{c}\text { No. of } \\
\text { positive }\end{array}$} & \multirow{2}{*}{$\%$} & \multicolumn{2}{|c|}{$\begin{array}{c}\text { Range of concentration } \\
\mu \mathrm{g} / \text { Liter }\end{array}$} & \multirow{2}{*}{$\begin{array}{c}\text { Mean } \pm \\
\text { S.E }\end{array}$} & \multicolumn{2}{|c|}{ Permissible limit of $\mathrm{FAO} / \mathrm{WHO}$} \\
\hline & & & & Minimum & Maximum & & $\begin{array}{c}\text { daily intake limit } \\
\mu \mathrm{g} / 60 \mathrm{Kg} \mathrm{B.W.}\end{array}$ & $\begin{array}{l}\text { limit in milk } \\
\text { P.P.m }\end{array}$ \\
\hline \multicolumn{9}{|c|}{ Organochlorine } \\
\hline P.P. DDT & 60 & 28 & $46.67 \%$ & 0.045 & 0.196 & $\begin{array}{c}0.090 \pm \\
0.020\end{array}$ & & 1.250 \\
\hline P.P. DDE & 60 & 29 & $18.33 \%$ & 0.080 & 0.197 & $\begin{array}{c}0.135 \pm \\
0.009\end{array}$ & 1200.0 & \\
\hline P.P. DDD & 60 & 23 & $38.33 \%$ & 0.033 & 0.206 & $\begin{array}{c}0.099 \pm \\
0.015\end{array}$ & & 0.020 \\
\hline Lindan & 60 & 27 & $45 \%$ & 0.011 & 0.059 & $\begin{array}{c}0.039 \pm \\
0.010\end{array}$ & 600.0 & \\
\hline Dieldrin & 60 & 18 & $30 \%$ & 0.060 & 0.165 & $\begin{array}{c}0.092 \pm \\
0.027\end{array}$ & 6.0 & 0.150 \\
\hline Aldrin & 60 & N.D & N.D & N.D & N.D & N.D & & \\
\hline \multicolumn{9}{|c|}{ Organophorous } \\
\hline Diazinon & 60 & 13 & $21.66 \%$ & 5.330 & 184.000 & $\begin{array}{c}130.12 \pm \\
24.6\end{array}$ & 0.2 & \\
\hline Malathione & 60 & 7 & $11.66 \%$ & 0.048 & 0.357 & $\begin{array}{c}0.107 \pm \\
0.036\end{array}$ & & \\
\hline Dursban & 60 & 5 & $8.33 \%$ & 0.098 & 0.348 & $\begin{array}{c}0.056 \pm \\
0.016\end{array}$ & 30.0 & \\
\hline Lannate & 60 & N.D & N.D & N.D & N.D & N.D & & \\
\hline Dimethoate & 60 & N.D & N.D & N.D & N.D & N.D & & \\
\hline Parathion & 60 & N.D & N.D & N.D & N.D & N.D & & \\
\hline Phosalone & 60 & N.D & N.D & N.D & N.D & N.D & & \\
\hline
\end{tabular}

Kafrelsheikh Vet. Med. J. Vol. 9 No. 1 (2011) 


\section{2- Effect of Pasteurization, Boiling and Sterilization on organochlorine} residues in milk:

The effect of heat treatment on the concentration of insecticides in buffalo's milk was illustrated in Table (2).The results revealed that pasteurization process causing reduction in each of p.p.DDT and p.p.DDE residues in a level of $26.47 \%$ and $9.52 \%$ respectively., while boiling process causing reduction by $11.76 \%$ and $7.14 \%$ in p.p.DDT and p.p.DDE respectively. These results are in accordance with that recorded by Abou-Donia et al., (2010).

On the other hand pasteurization and boiling causing increase by percentages of $22.80 \%$ and $18.42 \%$ in p.p.DDD residues. Such results are inagreement with those reported by Abdrabo et al. (1989), Amr et al. (1996), Samia (1997) and Nevin and Eman (2009). The increase of p.p.DDD level of may be due to decomposing of p.p.DDT and p.p.DDE during thermal treatment into p.p.DDD as reported by Dick et al., (1978) and Heschen et al., (1978).

Our results showed that Lindane and Dieldrin residues tend to be thermostable against pasteurization and boiling process. Slight reduction could be detected in linden and Aldrin by Abou-Donia et al., (2010).

Regarding to Table (2) sterilization process cause reduction in organo- chlorine residues of milk samples in a ratio of $29.41 \%, 26.16 \%$ on DDT and DDE respectively, while the ratio of DDD residues was increase to $11.40 \%$ by sterilization. These results are in agreement with those reported by Abou-Arab (1991) and Abou-Donia et al., (2010). The mean concentrations of organochlorine pesticides in raw, pasteurized and UHT milk samples are reported by Heck et al., (2007) who found that 
One-Way ANOVA revealed that p.p.DDD and total DDT levels were significantly higher in raw milk than in pasteurized and UHT milk, while p.p.DDDwas significantly higher in UHT than in raw milk.

However organocholorine pesticides and their residues are highly lipophilic nature and are hardly metabolized (Falandysz et al., 2004), they it may easily concentrate in fatty foods such as milk products leading to bioconcentration and biomagnifications through food chain (Darko and Acquaah, 2008).

\section{3- Effect of pasteurization, Boiling and sterilization on organo- phosphorous residues in milk:}

The result tabulated in Table (2) revealed that each of pasteurization, boiling and sterilization had a noticable effect in degradation of Diazinon, Malathion and Dursban residues where the reduction percentages as result of pasteurization were $7.677 \%, 46.97 \%$ and $42.85 \%$ respectively while the data were $23.26 \%, 56.59 \%$ and $57.14 \%$ due to boiling process and $40.162 \%, 59.44 \%$ and $72.34 \%$ for Diazinon, Malathion and Dursban respectively due to sterilization process. These results are nearly in agreement to those reported by Fekry and Bahout (1992) and Samia (1997). However, Korolev (1987) investigated the efficiency of heating the milk to 40,100 or $126^{\circ} \mathrm{c}$ in water bath for 15 or 30 minutes for decontamination of milk from Methatim and other organophosphorous insecticides. He concluded that thermal treatment at $100{ }^{\circ} \mathrm{c}$ and $126^{\circ} \mathrm{c}$ were effective in destruction of all examined organophosphorus insecticides residues at percentages of $93.3 \%$ and $100 \%$ respectively with exception of sebacyl which showed only $34-40 \%$ destruction. 
Detection Of Some Insecticide Residues In Milk And Influence ...

Table (2): Effect of heat treatment (Pasteurization, Boiling and Sterilization). On the level of insecticide residues in buffalo's raw milk samples.

\begin{tabular}{|c|c|c|c|c|c|c|c|}
\hline \multirow{2}{*}{\begin{tabular}{|c|} 
Type of heat treatment \\
Type of \\
Insecticides
\end{tabular}} & \multirow{2}{*}{$\begin{array}{c}\text { Raw milk } \\
\text { Mean } \pm \\
\text { S.E }\end{array}$} & \multicolumn{2}{|c|}{ Pasteurized milk } & \multicolumn{2}{|c|}{$\begin{array}{c}\text { Boiling } \\
\text { milk }\end{array}$} & \multicolumn{2}{|c|}{ Sterilized milk. } \\
\hline & & $\begin{array}{c}\text { Mean } \pm \\
\text { S.E }\end{array}$ & degradation \% & $\begin{array}{c}\text { Mean } \pm \\
\text { S.E }\end{array}$ & $\begin{array}{c}\text { degradation } \\
\%\end{array}$ & $\begin{array}{c}\text { Mean } \pm \\
\text { S.E }\end{array}$ & degradation $\%$ \\
\hline \multicolumn{8}{|l|}{ Organochlorine } \\
\hline P.P. DDT & $\begin{array}{c}0.034 \pm \\
0.053\end{array}$ & $\begin{array}{c}0.025 \pm \\
0.051\end{array}$ & 26.47 & $\begin{array}{c}0.030 \pm \\
0.044\end{array}$ & 11.76 & $\begin{array}{c}0.024 \pm \\
0.06\end{array}$ & 29.41 \\
\hline P.P. DDE & $\begin{array}{c}0.042 \pm \\
0.037\end{array}$ & $\begin{array}{c}0.030 \pm \\
0.026\end{array}$ & 9.52 & $\begin{array}{c}0.039 \pm \\
0.099\end{array}$ & 7.14 & $\begin{array}{c}0.031 \pm \\
0.077\end{array}$ & 26.16 \\
\hline P.P. DDD & $\begin{array}{c}0.114 \pm \\
0.066\end{array}$ & $\begin{array}{c}0.140 \pm \\
0.078\end{array}$ & 22.80 & $\begin{array}{c}0.135 \pm \\
0.098\end{array}$ & 18.42 & $\begin{array}{c}0.127 \pm \\
0.087\end{array}$ & 11.40 \\
\hline Lindan & $\begin{array}{c}0.0125 \pm \\
0.059\end{array}$ & $\begin{array}{c}0.0123 \pm \\
0.057\end{array}$ & $\begin{array}{l}\text { Thermostabl } \\
\text { or no change }\end{array}$ & $\begin{array}{c}0.0123 \pm \\
0.057\end{array}$ & No change & $\begin{array}{c}0.0124 \pm \\
0.056\end{array}$ & No change \\
\hline Dieldrin & $\begin{array}{c}0.090 \pm \\
0.024\end{array}$ & $\begin{array}{c}0.091 \pm \\
0.023\end{array}$ & & $\begin{array}{c}0.090 \pm \\
0.024\end{array}$ & & $\begin{array}{c}0.090 \pm \\
0.024\end{array}$ & \\
\hline \multicolumn{8}{|l|}{ Organophorous } \\
\hline Diazinon & $\begin{array}{c}130.12 \pm \\
24.60\end{array}$ & $\begin{array}{c}120.130 \pm \\
11.21\end{array}$ & 7.677 & $\begin{array}{c}99.850 \pm \\
9.66\end{array}$ & 23.26 & $\begin{array}{c}77.860 \pm \\
7.55\end{array}$ & 40.162 \\
\hline Malathione & $\begin{array}{c}0.364 \pm \\
0.099\end{array}$ & $\begin{array}{c}0.193 \pm \\
0.065\end{array}$ & 46.970 & $\begin{array}{c}0.158 \pm \\
0.086\end{array}$ & 56.59 & $\begin{array}{c}0.146 \pm \\
0.067\end{array}$ & 59.44 \\
\hline Dursban & $\begin{array}{c}0.049 \pm \\
0.042\end{array}$ & $\begin{array}{c}0.028 \pm \\
0.08\end{array}$ & 42.850 & $\begin{array}{c}0.021 \pm \\
0.007\end{array}$ & 57.14 & $\begin{array}{c}0.013 \pm \\
0.005\end{array}$ & 72.34 \\
\hline
\end{tabular}

\section{4- Effect of yoghurt processing on the level of insecticides residues in milk:}

The fermented dairy products such as yoghurt are also important since their beneficial effects make them available components in the diet of infant, children and Elderly. The results tabulated in Table (3) revealed that processing of milk into yoghurt reduced the level of organochlorine insecticides residues at percentages of $44.11 \%, 57.14 \%$, $5.26 \% 36 \%$ and $25.55 \%$ for DDT, DDE, DDD, Lindan and Dieldrin $\overline{\text { Kafrelsheikh Vet. Med. J. Vol. } 9 \text { No. } 1 \text { (2011) }}$ 
respectively. These results are nearly similar to those reported by $\boldsymbol{A b o u}$ Arab (1991), Samia (1997), Darko and Acquaah (2008) and AbouDonia et al., (2010) which show that the manufacture of yoghurt from buffalo's milk result in reducing the level of studied pesticides such as Lindan, Aldrin, DDT, DDE, and DDD. The reduction may be due to the heat treatment of milk $80-82^{\circ} \mathrm{c}$ for $20 \mathrm{~min}$. and as the activity of yoghurt starter culture (S.thermophillus and L. bulgricus).Yoghurt processing reduced the organophosphorous residues in milk by $9.25 \%, 47.80 \%$ and63.26\% for Diazinon, Malathione and Dursban respectively .It may be attributed to milk protein adsorption, bacterial cell incorporation and or microbial degradation Magdoub et al.,(1989)These results are in coordinated with those reported by Gajduskova and Lat(1974).In this aspect, Abou-Arab (1997) reported that milk processing technologies have an important role in reduction of insecticide residuesin milk products and supplying safe food for human than raw milk. Furthermore, the residues contents in dairy products reflect their regional environmental contamination and may be of great value for scientific and public health knowledge.

The present result can conclude that heat treatment more effective in degradation of insecticides, in addition to the manufacture of yoghurt decreased the level of studied insecticides. Since the consumption of milk products may be safer than raw milk so we recommended that:

1- It is preferred that milk contaminated with insecticides under go industrial manufacture instead of consumption of milk as raw milk.

2- Regulations and control using of these insecticides to minimize or eliminate the hazard resulting from miss use of these compounds. 
Detection Of Some Insecticide Residues In Milk And Influence ...

Table (3): Effect of yoghurt processing (Bacterial fermentation). On the level of insecticide residues in buffalo's raw milk samples.

\begin{tabular}{|c|c|c|c|}
\hline \multirow{2}{*}{$\begin{array}{c}\text { Type of } \\
\text { Insecticides }\end{array}$} & \multirow{2}{*}{$\begin{array}{c}\text { Raw milk } \\
\text { Mean } \pm \text { S.E }\end{array}$} & \multicolumn{2}{|c|}{ yoghurt } \\
\hline & & Mean \pm S.E & degradation $\%$ \\
\hline \multicolumn{4}{|l|}{ Organochlorine } \\
\hline P.P. DDT & $0.034 \pm 0.053$ & $0.019 \pm 0.082$ & 44.11 \\
\hline P.P. DDE & $0.042 \pm 0.037$ & $0.018 \pm 0.081$ & 57.14 \\
\hline P.P. DDD & $0.114 \pm 0.066$ & $0.120 \pm 0.75$ & 5.26 \\
\hline Lindan & $0.0125 \pm 0.059$ & $0.017 \pm 0.004$ & 36 \\
\hline Dieldrin & $0.090 \pm 0.024$ & $0.067 \pm 0.018$ & 25.55 \\
\hline \multicolumn{4}{|l|}{ Organophorous } \\
\hline Diazinon & $130.12 \pm 24.60$ & $118.08 \pm 20.59$ & 9.25 \\
\hline Malathione & $0.364 \pm 0.099$ & $0.19 \pm 0.040$ & 47.80 \\
\hline Dursban & $0.049 \pm 0.042$ & $0.018 \pm 0.05$ & 63.26 \\
\hline
\end{tabular}

\section{REFERENCES}

- Abd-Alla, E.A.M.;Sayed,A.F.andAhmed,N.S.(1991): Incidence of some organophosphrous pesticides residues in buffaloes' milk Giza Governorate. Egyptian J.Dairy Sci, 19:243-248.

- Abdrabo, F.H.; Ahmed, N.S. and Abou Dawood, A.E. (1989): Organochlorine, organophosphorus and carbamate pesticides cause changes in some properties of buffaloe's milk. Egyptian J. Dairy Sci., 17:105-113.

- Abou-Arab, A.A.K. (1991): Microbiological quality of dairy products in relation to some pollutants. Ph. D. Thesis, Fac. Of Agric. Ain. Shams University. 
- Abou-Arab, A.A.K. (1996): Fate of some pollutants in various papers fed to lactating buffaloes and their effect on the milk. J. Agric. Sci. Mansoura Univ., 21:1385-1395.

- Abou-Arab, A.A.K. (1997): Effect of Ras cheese manfacturing on the stability of DDT and its metabolites. J. food chemistry, 59:115-119.

- Abou-Donia, M.A.; Abou-Arab, A.A.k.; Enb, A.; EL-Senaity, M.H. and Abdrabo, N.S. (2010): Chemical composition of raw milk and the accumulation of pesticide residues in milk products. Global Veterinaria 4(1):6-14.

- Ali, A.A.; Metwally, M.M.; Ahmed, N.S.and EMB, A.K. (1993): Pesticide residues in milk and distribution among dairy products. Egyptian J. Dairy Sci, 21:291-299.

- Amoah, P.; Drechsel, P.; Abaidoo, R.C.; and Ntow, W.J. (2006): Pesticide and pathogen contamination of vegetables in Ghana's urban markets. Arch Environ. Contam. Toxicol. 50:1-6.

- Amr, M.M. (1992): Health profile of workers chronically exposed to pesticides in two Large -scale formulation plants in Egypt. Pesticide intoxication (IDRC-Cairo University).project phase 1(1987-1990). pesticide 90, proceeding, Ottawa, Canada.

- Amr, M.M.; Moursy, A.W.; Hafez, R.S.; Dogheim, S.M.A. andAbouzeid, A.M. (1996): Pesticide residues in milk and dairy products in Egypt. Proceeding of conference on food-borne contamination and Egyptian's health. 
- Antunes-Madeira, M.C.; Almeida, L.M.; and Madeira, V.M.C. (1993): depth-dependent effects of DDTand Lindan on the native membranes and extracted Lipids implication for mechanisms of toxicity. Bulletin of Environmental Contamination andToxicity, 5:787-794.

- A.O.A.C. (1995): Official Methods of the Association Official Analytical Chemists, Washington.D.C.

- Battu, R.S.; Balwider, S.and Kang, B.K. (2004): Contamination of liquid milk and butter with pesticide residue in the Ludhiana district of Punjab state, India. Ecotoxicology and Environment Safety.59 (3): 324-331.

- Beach, T.M.and Whalen,M.M. (2006): Effects of organochlorine pesticides on interleukin secretion from lymphocytes Hum. Exp. Toxicol., 25:651-659.

- Camoni, L.; Ghirothi, M.; Menegh, D.; Diverio, S.; Generali, T.; Izzo, P.and Mwaka, B. (1990): Cherofenvin phos. Residues in milk, from traditionally managed cows in southern province. Zambia Veterinary research communications.14 (6):503-506.

- Chowdhury, A. p.; gautan, A. K. and Bhatnagar, V. k.(1990): Lindan induces changes in morphology and lipids profile of testes in rats. J. of Biomedica.Biochimica Acta, 49:1059-1065.

- Curus, C.F. (1994): Showed DDT continues to be recommended for malaria vector control? Med.Vet.Entomol. 8:101-112.

- Darko, J.and Acquaah, S.O. (2008): Levels of organochlorine pesticide residues in dairy products in Kumasi, Ghana. Chemosphere, 71:294-298. 
- Dick, G.L.; Heenan, M.P.; Love, J.L.; Udy, P.B.andDavidson, F. (1978): Survey of trace elements and pesticides residues in the New Zealand diet.II organochlorine and organophosphorous pesticide residues content.NewZealand J.Sci, 21,71C.f.Dairy Sci, Abst 41 (3878).

- Dixon,R.L.(1980): Toxic responses of the reproductive system in Casarett and Doull's Toxicity. The Basic Science of Poison. J. Doull. C-klassen and M. Andur (eds) 2nd ed. Chapter 15, Macmillan publ. Co., New Yourk.

- Dogheim, S.M.; Nasr, E.N.; Almazandm, M.m.; and ELTohamy, M. (1989):Pesticide residues in milk and fish Samples collected from Two Egyptian Governorates .Journal of the association of Official Analytical Chemists.73(1)19-21.

- Downey, W.K. (1971): Pesticide residues in milk and milk products. IDF55. Session, Dublin.

- Ebbing, D. D. and Wrighton, M.S. (1987): General chemistry.2nd Ed, Houghton Mifflin, Boston, and PP: 103-117.

- ELGhannan, M.; Salem, S. and Abdel-Shaheed, A. (1987): Pesticide residues in raw milk .Egyptian J.Dairy Sci.,15:187-192.

- E.O.S. (1970): Egyptian Organization for standardization Egyptian Standards No: 1000, fermented milk.

- Falandysz, J.; Barska, A.; Garbacik, W.; Wesolowska and Szefer, P. (2004): Organochlorine pesticides and PCBs in perch Perca Fluvialilis from the Odra/Oder river estuary, Baltic Sea. Food Chemistry, 87:1723. 
- Fekry, M.F. and Bahout .A.A. (1992): Effect of heat treatment on milk contaminated with Diazinon as an environmental pollutant. The new Egyptian Journal of Medicine Vol. 7 NO 2:367-372.

- Fontcuberta, M.; Arques, J. F.; Villaalbi, J. R.;: Martinez, M.; Centrich, F.; Serrahima, E.; Pineda, L.; Duran, J. and Casas, C. (2008): Chlorinated organic pesticides in marketed food Barceloma, 2001-2006. Science of the Total Environment: 389:52-57.

- Food and Agriculture Organization / World Health Organization (FAO/WHO) (1972): Pesticide residues in food. Report of the 1971 Joint meeting of FAO Working part of experts on pesticide residues and the WHO experts committee.

- Gajduskova, V.; and Lat,M. (1974): Effect of heat treatment on organophosphorous pesticide residues residues in milk and milk products Prumysal potravin (1974) 25(3):95-96.

- Heck, M. C.; Santos, J. S.; Bogusz Tunior, S.; Costabeber, I. and Emanuelli, T.(2007): Estimation of children exposure to organochlorine compounds through milk in Rio Grando.DoSul, Brazil Food Chemistry, 102:288-294.

- Heschen, W.;Bulthgen, A.andTolle, $A$. (1978): Residue of chlorinated hydrocarbons in milk and milk products .Situation and evaluation.

- IDF. (1979): International Dairy federation Bulletin, Chemical Residues in milk and milk products.I.D.f.Document, pp: 133.

- Jaga, K.and Dharmani, C. (2005): The epidemiology of pesticide exposure and cancer; a review .Rev.Environ health.20:15-38. 
- Kannan, K.; Tanabe, S.; Ramesh, A.; Subramanian, A. and Tatsukawa, R. (1992): persistent organochlorine residues in food stuffs from India and their implications on human dietary exposure. J. Agric. Food Chem.40:518-524.

- Kholif, A.M.; Abou-El-Nor, S.; Abou-Arab, A.A.KandAlamy, H.A.E.L. (1994): Effect of spraying diazinon to control the external parasites on the productive performance of dairy animal's .Yield and composition of buffalo's and Friesian cow's milk. Egyptian J.Dairy Sci., 22:145-154.

- Korolev, B.A. (1987): Decontamination of milk containing pesticides residues .Hygiena Sanitariya No.7:29-31.

- Lembowiez, K.; Sitarska, E.; Garski, T. and Ludwicki, J.K. (1991): The effect of organic chlorine compounds and their metabolites present in human milk on new born mice.Toxicology Letters, 57:215226.

- Magdoub, M.N.I.; Fayed, A.E.; EL-Shenawy, M.A.Abou-Arab, A.A.K. (1989): Persistence of fenvalerate pyrethroid in milk in relation to lactic acid bacteria .Egyptian J.Dairy Sci., 17:217-225.

- Nevin, S. Ahmed and Eman, S. Zaki (2009): Detection of some organochlorine pesticides in raw milk in Giza governorate. Journal of Applied Sciences Research, 5(12): 2520-2523.

- Pagliuca, G.; Serraino, A.; Gazzotti, T.; Zironi, E.; Borsari .A; Rosmini, $\boldsymbol{R}$. (2006): Organophosphorus pesticides residues in Italian raw milk. JDairy Res. 73(3): 340-4

- Pesticide Analytical Manual (1991): Pesticide Analytical Manual, Vol.1, Multiresidue Method, Food and Feed .U.S. Department of Health and Human Services. Public Health Service, Food and Drug Administration. 
- Samia M.El.Hosshy (1997): Insecticide residues in milk and influence of heat treatments and bacterial fermentation as safeguard against these pollutants .Assiut vet. Med .J.Vol.37No.73, April 1997.

- Snelson, J.t.; and Tuinstra, L.G. (1979): International Dairy Federation, Document, 113:6.

- Sitarska, E.; Klueinski, W.; Winnicka, A.; Ludwicki, J. (1991): Residues of organochlorine pesticides in milk gland secretions of cows in prenatal period. Bulletin of Environmental Contamination and Toxicology, 47:817-821.

- Stijve, T.(1984): Determination and occurrence of organophosphorous pesticides residues in milk .Royal society of Chemistry No.49: 293302.

- Toyoda, M.; Adachi, T.; Nada, IDA. and Minagawa, N. (1990): Simple analytical method for organ phosphorous pesticide in milk. j. Assoc. Anal. Chem. 73, (5)770-772.

- Waliszewski, S. M.; Pardio, V. T.; Chantiri, J. M.; Aguirre, A. A.; Infanzon, $R$. M. and Rivera.(1997):Organochlorine pesticide residues in cow's milk and butter in Mexico. The science of the total Environment,208:127-132.

- Waliszewski, S.; GomezArroyo, M.; INfanzo, S.; Carvajal, O.; villabos-pietrini, R.; Trujill, O. and Maxwell, P.(2004): Persistent organochlorine pesticide level in bovine fat from Mexico Food Additives and contaminants.21 (8)774-780.

- WHO. (1973): Pesticide residues in food .vol.2, 2nd Ed, Food standard program Codex Alimentarius Commission. Report paper 62:25-35. 


\section{الكشف عن وجود بعض المبيدات الحشرية في الألبان وتأثير المعاملات الحرارية والتخمر البكتيري ضد هذه المبيدات}

أجري هذا البحث للكثف عن وجود بقايا بعض المبيدات الحشرية في الألبان. وقد تم تحليل (7) ستون عينة من اللبن الجاموسي فى محافظة بورسعيد. وقد أسفرت النتائج عن وجود مبيدات

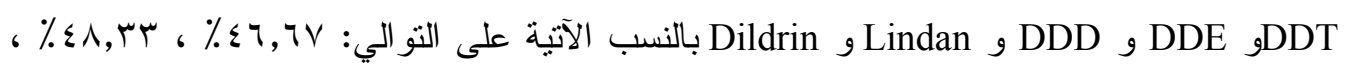

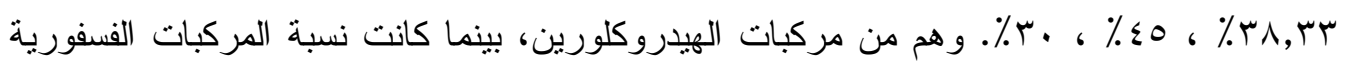

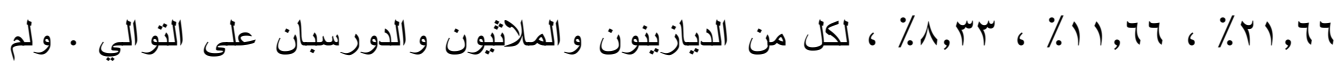
تتعدى كل من النسب الناتجة للمركبات، النسب المسموح بها. أما نأثير المعاملات الحرارية المختلفة وتصنيع اللبن إلى زبادي على هذه المتبقيات فقد أظهرت النتائج تأثثراً ايجابيا في تكسير متبقيات المبيدات الحشرية في اللبن ، فقد اختزلت النسب الناتجة في المركبات الهيدروكلورونيه (عدا نسبة التي زادت بعض الثشئ عن النسبة قبل المعالجة الحرارية) و المركبات الفسفورية وقد نوقتت الأهية الصحية لمتقيات المبيدات الحشرية في اللبن و الاحتياطات الواجب اتخاذها أو التخلص من تلوث الألبان بهذه المبيدات وحماية المستهلك ضد هذا التأثير الخطير لهذه الملوثات. 